\title{
Persimmon (Diospyros Kaki L.) Alleviates Ethanol-Induced Gastric Ulcer in Rats
}

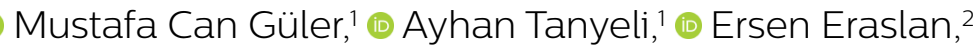 \\ D Mehmet Ramazan Bozhüyük, ${ }^{3}$ (1) Fazile Nur Ekinci Akdemir, ${ }^{4}$ \\ (1) Erdem Toktay, ${ }^{5}$ (1) Nezahat Kurt, ${ }^{6}$ (1) Esra Çapanoğlu Güven, ${ }^{7}$ (ㄷ) Gülay Özkan
}

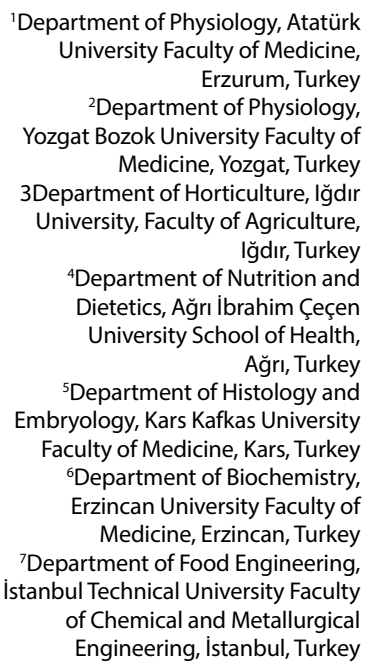

'Department of Physiology, Atatürk University Faculty of Medicine Erzurum, Turkey

${ }^{2}$ Department of Physiology, Yozgat Bozok University Faculty of Medicine, Yozgat, Turkey 3Department of Horticulture, Iğdır University, Faculty of Agriculture, Iğdır, Turkey

${ }^{4}$ Department of Nutrition and Dietetics, Ağrı İbrahim Çeçen University School of Health, Ağrı, Turkey

${ }^{5}$ Department of Histology and Embryology, Kars Kafkas University

Faculty of Medicine, Kars, Turkey

${ }^{6}$ Department of Biochemistry,

Erzincan University Faculty of

Medicine, Erzincan, Turkey

${ }^{7}$ Department of Food Engineering, İstanbul Technical University Faculty of Chemical and Metallurgical Engineering, İstanbul, Turkey

Submitted: 18.08.2020 Accepted: 08.12.2020

Correspondence: Ayhan Tanyeli, Atatürk Üniversitesi Tıp Fakültesi, Fizyoloji Anabilim Dalı, Erzurum, Turkey

E-mail: ayhan.tanyeli@atauni.edu.tr

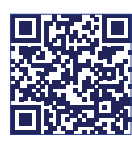

Keywords: Cytokine; ethanol; gastric ulcer; persimmon fruit extract; rat.

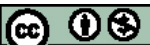

This work is licensed under a Creative Common Attribution-NonCommercial 4.0 International License.

\begin{abstract}
Objective: The worldwide incidence of a gastric ulcer is high, most often as a result of use of nonsteroidal anti-inflammatory drugs, excessive alcohol consumption, or Helicobacter pylori infection. An ethanol-based gastric ulcer model in rats was used to examine the effect of persimmon (Diospyros kaki L.) extract as a potential form of treatment.
\end{abstract}

Methods: Two dosages of persimmon extract were applied in a gastric ulcer model created with $5 \mathrm{~mL} / \mathrm{kg}$ ethanol in Wistar albino rats. Histopathological and biochemical methods were used to assess any gastroprotective effects.

Results: Persimmon extract significantly decreased the level of the cytokines interleukin (IL)- I0, IL-6, tumor necrosis factor alpha (TNF- $\alpha$ ) and IL-I beta. Caspase- 3 and nuclear factor kappa $B$ expression was also significantly reduced.

Conclusion: Persimmon fruit extract demonstrated a gastroprotective effect in an ethanol-based gastric ulcer model in rats.

\section{INTRODUCTION}

The etiology of a gastric ulcer can be complicated and the morbidity and mortality rate can be significant. ${ }^{[1]}$ Although there have been many developments in gastric ulcer therapies, the prevalence worldwide continues to be substantial. $^{[2]}$ Exposure to stress, nonsteroidal anti-inflammatory drug use, the presence of Helicobacter pylori ( $H$. pylori), and excessive alcohol consumption may lead to the devel- opment of a gastric ulcer. ${ }^{[3,4]}$ Ethanol damages the gastric mucosa through the vascular endothelia and increases the level of reactive oxygen radical species (ROS). ${ }^{[5]}$

Caspase 3 is a member of the cysteine protease family and plays a role in inflammation and apoptosis. ${ }^{[6,7]}$ Nuclear factor-kappa $B(N F-\kappa B)$ regulates the expression of various genes related to inflammation. ${ }^{[8]}$ Interleukin (IL)- I beta (IL$I \beta)$ is a proinflammatory cytokine, and inflammation in- 
duces IL-6 synthesis. ${ }^{[9,10]}$ IL- 10 has a role in suppressing the expression of proinflammatory cytokines. ${ }^{\left[{ }^{\prime \prime}\right]}$

Ethanol consumption reduces the anti-inflammatory cytokine (IL-I0) level and can lead to an overexpression of tumor necrosis factor alpha (TNF- $\alpha) \cdot{ }^{[12]}$ Antioxidant substances can provide a gastroprotective effect against ethanol-induced gastric ulcer. ${ }^{[13]}$

Persimmon (Diospyros kaki L.) has been shown to have various beneficial effects on human health. ${ }^{[14]}$ Persimmon fruit has been reported to reduce ROS levels. ${ }^{[15]}$ The chemical examination of persimmon fruit has revealed phenol compounds that act as antioxidants. ${ }^{[16,17]}$

In the current study, a gastric ulcer model was used to examine inflammatory parameters using persimmon fruit extract. Molecular and histopathological methods were also used to analyze apoptosis. These biochemical and histopathological parameters were studied to assess the potential protective effects of persimmon fruit extract on an ethanol-induced gastric ulcer.

\section{MATERIALS AND METHODS}

\section{Preparation of persimmon fruit extract}

The persimmon (Diospyros kaki L.) fruit used in the experiments was harvested from Mersin province in Turkey in the ninth month. The fruit was washed, cleaned, and cut into small pieces, and the seeds were removed. The fresh fruit was then homogenized as previously described to obtain the juice. ${ }^{[18]}$ The pulpy juice (extract) was orally administered to the study groups at $4 \mathrm{~mL} / \mathrm{kg}$ and $8 \mathrm{~mL} / \mathrm{kg}$ doses (gavage) for 10 days in single doses.

\section{Animals}

The rats were acquired from the Atatürk University Experimental Animal Research Center. The subjects were housed in wire cages with appropriate laboratory conditions: $22 \pm 2{ }^{\circ} \mathrm{C}$ temperature, 12-hour light/dark cycle, and $5 \pm 5 \%$ humidity. Standard rat feed (pellets) and tap water were available ad libitum.

\section{Ethanol-induced gastric ulcer and treatment}

A total of 32 Wistar Albino male rats weighing 250-300 $g$ were used in the study. Four groups of 8 rats were randomly formed: Group I (control group): distilled water was administered by oral gavage for 10 days; Group 2 (ulcer): no treatment was performed until the ethanol administration phase; Group 3 (persimmon, $4 \mathrm{~mL} / \mathrm{kg}$ ); and Group 4 (persimmon, $8 \mathrm{~mL} / \mathrm{kg}$ ). Intragastric administration of the persimmon extract was performed for 10 days in both persimmon groups. All of the animals fasted for I day (24 hours) before the ethanol administration. In Groups 2, 3, and 4, $5 \mathrm{~mL} / \mathrm{kg}$ absolute ethanol (99\%) was administrated orally (gavage) on the $\mathrm{I}^{\text {th }}$ day. Euthanasia was performed 90 minutes after the ethanol application.

\section{Ethical approval}

The study design was approved by the Ataturk University Local Research Animal Ethics Committee on April 19, 2016 (no: 70).

\section{Tissue collection}

The gastric tissue was cut from the minor and major curvatures and washed with saline to remove the stomach contents. Images of the clean gastric tissue were recorded with a digital camera for macroscopic evaluation. The tissue was preserved with $10 \%$ formaldehyde at $-80^{\circ} \mathrm{C}$ for histopathological and biochemical analyses.

\section{Gastric tissue homogenization}

Ice-cold saline was used to wash the tissue samples. Phosphate-buffered saline (PBS; $50 \mathrm{mM}, \mathrm{pH}$ 7.4) was used with an iced mammalian protease inhibitor cocktail as the tissue homogenate (10\%). The homogenate preparation was centrifuged at $3000 \times \mathrm{g}$ for 15 minutes at $4^{\circ} \mathrm{C}$. The supernatants were used to measure and analyze various biochemical markers.

High-performance liquid chromatography analysis High-performance liquid chromatography (HPLC) paired with a photodiode array (HPLC-PDA) was used to generate $\mathrm{mg} / 100 \mathrm{~mL}$ samples. Catechin, $\mathrm{p}$-Coumaric acid, caffeic acid, syringic acid, gallic acid, 4-hydroxy benzoic acid, vanillic acid, chlorogenic acid, ferulic acid, delphinidin-3-glucosidase, and cyanidin-3-glucosidase were used to prepare standard calibration curves. An A 0.45- $\mu \mathrm{m}$ membrane filter was used and each filtered sample $(1 \mathrm{~mL})$ was placed in a vial and evaluated using HPLC (W600 system with 996 photodiode array detector; Waters Corp., Milford, MA, USA). A CI8 column (Luna Omega; Phenomenex Inc., Torrance, CA, USA) was heated to $40^{\circ} \mathrm{C}$.

The mobile phase was composed of solvent A (distilled water with $0.1 \% \mathrm{v} / \mathrm{v}$ trifluoroacetic acid [TFA]) and acetonitrile with $0.1 \% \mathrm{v} / \mathrm{v}$ TFA, and solvent B (acetonitrile with $0.1 \% \mathrm{v} / \mathrm{v}$ TFA). A linear gradient was used: at 0 minutes, $95 \%$ solvent $A$ and $5 \%$ solvent $B$; at 45 minutes, $65 \%$ solvent $A$ and $35 \%$ solvent $B$; at 47 minutes, $25 \%$ solvent $A$ and $75 \%$ solvent $B$; and at 54 minutes a return to initial conditions. The rate of flow was I $\mathrm{mL} /$ minute. Chromatograms were recorded at $280,312,360$, and $520 \mathrm{~nm}$. Retention time determined the identification and quantification, using the standard ultraviolet spectra and external curves. ${ }^{[19]}$

Measurement of IL-10, TNF- $\alpha$, IL-6, and IL-1 $\beta$ levels in gastric tissue

The IL-10, IL-I $\beta$, TNF- $\alpha$, and IL- 6 levels of the gastric tissue homogenates were gauged using rat immunoassay enzyme-linked immunosorbent assay kits (Elabscience, Wuhan, China).

\section{Hematoxylin and eosin analyses}

The gastric samples were preserved in 10\% formaldehyde 
for 48 hours. Next, they were dehydrated with alcohol and cleared with a xylene series. Following paraffin fixation, the samples were cut into $5-\mu \mathrm{m}$ sections with a microtome (RM2235; Leica Microsystems, Wetzlar, Germany). Hematoxylin eosin staining was performed for histopathological examination using light microscopy.

Immunohistochemical analysis

Nuclear factor kappa B (NF-KB) (Abcam, Cambridge, UK) and caspase- 3 (Novus Biologicals, Littleton, CO, USA) were used to evaluate the apoptotic and inflammatory properties immunohistopathologically. Following deparaffinization, the samples were rehydrated with water, ethanol, and phosphate-buffered saline (PBS). They were washed with distilled water and immersed in $3 \%$ hydrogen peroxide for 15 minutes. PBS and equilibration buffer were used for 20 minutes at room temperature. An anti-caspase- 3 solution was used for the incubation of the sections at room temperature for I hour. The sections were incubated with PBS containing normal goat serum, without a primary antibody. Counterstaining with Mayer's hematoxylin was performed, and following that, the sections were examined under a light microscope $(\mathrm{BH}-40$; Olympus Corp., Tokyo, Japan).

Table I. Phenolic content of persimmon samples

\begin{tabular}{lcc}
\hline Phenolic substances & Average (ppm) & SD \\
\hline Gallic acid & 57.62 & 8.85 \\
Catechin & 6.18 & 0.75 \\
Procyanidin BI & 2.39 & 0.60 \\
Procyanidin B2 & 5.06 & 0.56 \\
Epicatechin & $1.6 \mathrm{I}$ & 0.24 \\
P-Coumaric acid & 0.18 & 0.03 \\
Vanillic acid & 0.71 & 0.02 \\
Chlorogenic acid & 0.23 & 0.06 \\
Syringic acid & 30.05 & 1.29 \\
Cinnamic acid & $5.6 \mathrm{I}$ & 0.16 \\
Rutin & $2.4 \mathrm{I}$ & 0.03 \\
Cyanidin-3-glucosidase & 3.70 & 3.01 \\
\hline
\end{tabular}

High-performance liquid chromatography results; all experiments were conducted at least 3 times.

\section{Statistical analysis}

Statistical analyses were performed using IBM SPSS Statistics for Windows, Version 20.0 (IBM Corp., Armonk, NY, USA). All of the data were presented as mean \pm SD. The group differences were examined using one-way anal$y$ sis of variance. $P<0.05$ was considered significant. All of the fruit extract experiments were performed at least 3 times.

\section{RESULTS}

\section{The HPLC analysis of persimmon (Diospyros kaki L.) fruit extract}

The phenolic compounds of the persimmon samples are shown in Table I.

\section{IL-10, IL-6, IL-1 $\beta$, and TNF- $\alpha$ levels}

It was determined that the proinflammatory and anti-inflammatory cytokine levels differed significantly between groups. The IL-I $\beta$, IL- I0, IL-6, and TNF- $\alpha$ levels in the ulcer group were significantly higher than those of the control group $(p<0.00 \mathrm{I})$. In the groups treated with persimmon, the IL-I0, TNF- $\alpha$, IL- 6 , and IL-I $\beta$ levels were significantly lower than those seen in the ulcer group $(p<0.00 I)$ (Fig. I).

\section{Hematoxylin and eosin analyses}

The hematoxylin and eosin scores are presented in Table 2. The histopathological evaluation of the gastric mucosa can be seen in Figure 2.

In the control group, the mucosal cells were of normal shape and size, and the gastric pits were regular. In the ulcer group, the gastric pits were irregular, and no longer had a normal appearance. The mucosal cells were necrotized in the superficial and the deep mucosa, and the number of lymphocytes increased. In the group that received $4 \mathrm{~mL} / \mathrm{kg}$ persimmon extract, the gastric pits were regular and had a normal appearance. Hypertrophic changes were seen in the surface mucosal cells. In the Persimmon $8 \mathrm{~mL} /$ $\mathrm{kg}$ group, the gastric pits were regular with an appearance similar to that of the control group.
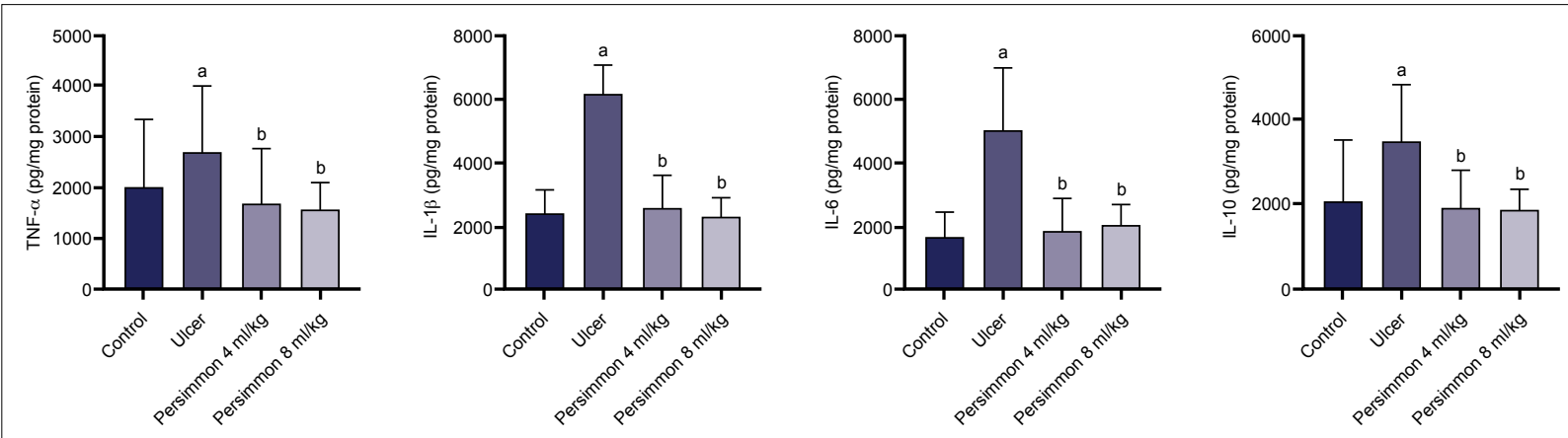

Figure 1. Effect of persimmon on some cytokine levels in a rat model of ethanol-induced gastric injury. IL: Interleukin; TNF-a: Tumor necrosis factor alpha. 
Table 2. Hematoxylin and eosin staining scores, and NF- $\mathrm{KB}$ and caspase-3 expression of the study groups

\begin{tabular}{lcccc}
\hline Groups/parameters & H\&E & NF-KB immunoreactivity & Caspase-3 immunoreactivity \\
\hline Control & ++ & ++ & ++ \\
Ulcer & +++ & +++ & ++ \\
Persimmon $4 \mathrm{~mL} / \mathrm{kg}$ & ++ & ++ & ++ & ++ \\
Persimmon $8 \mathrm{~mL} / \mathrm{kg}$ & ++ & ++ & + \\
\hline
\end{tabular}

+: Mild damage; ++: Medium damage; +++: Severe damage. H\&E: Hematoxylin and eosin.

\section{Immunohistochemical observation}

The NF- $\mathrm{BB}$ and caspase-3 expression scores are presented in Table 2. The immunohistochemical evaluation of caspase -3 and NF- $\kappa$ B staining can be seen in Figure 2. The ulcer group demonstrated significant immunopositivity. The control group and both persimmon-treatment groups showed mild immunopositivity.

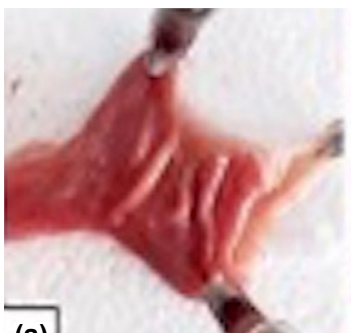

(a)

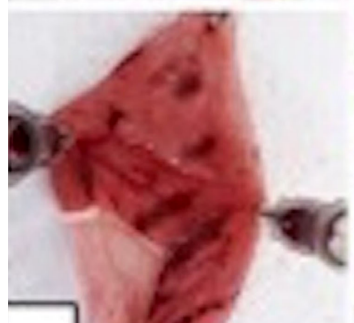

(b)
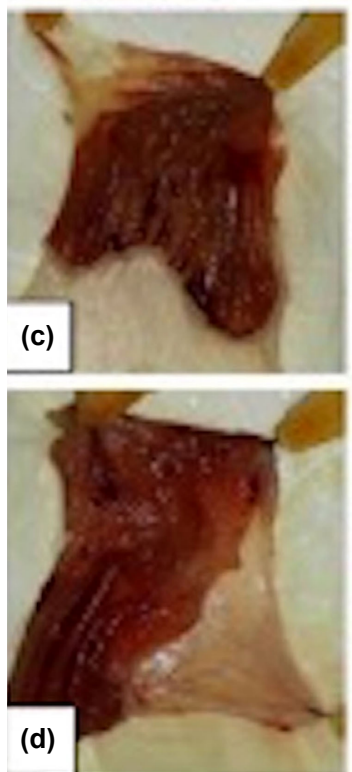

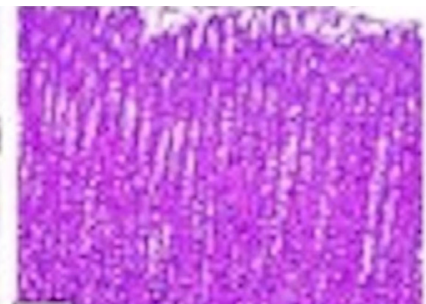

(a)

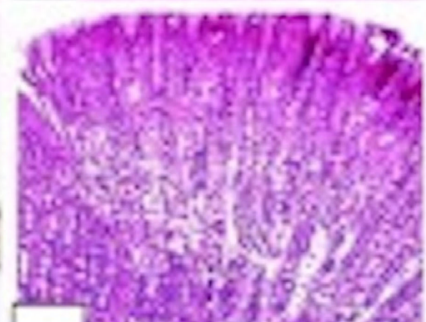

(b)
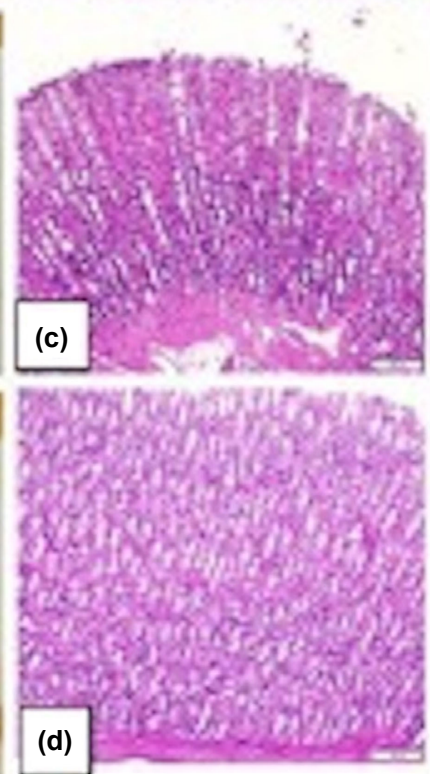

\section{DISCUSSION}

Gastric ulcer is a common digestive disorder. ${ }^{[1]}$ Ethanol can directly injure the gastric mucosa, resulting in hemorrhagic lesions, edema, subepithelial hemorrhage, and cellular exfoliation with the rupture of the mucosa. ${ }^{[20]}$ TNF- $\alpha$ not only induces IL- 6 and IL-I $\beta$ production, but
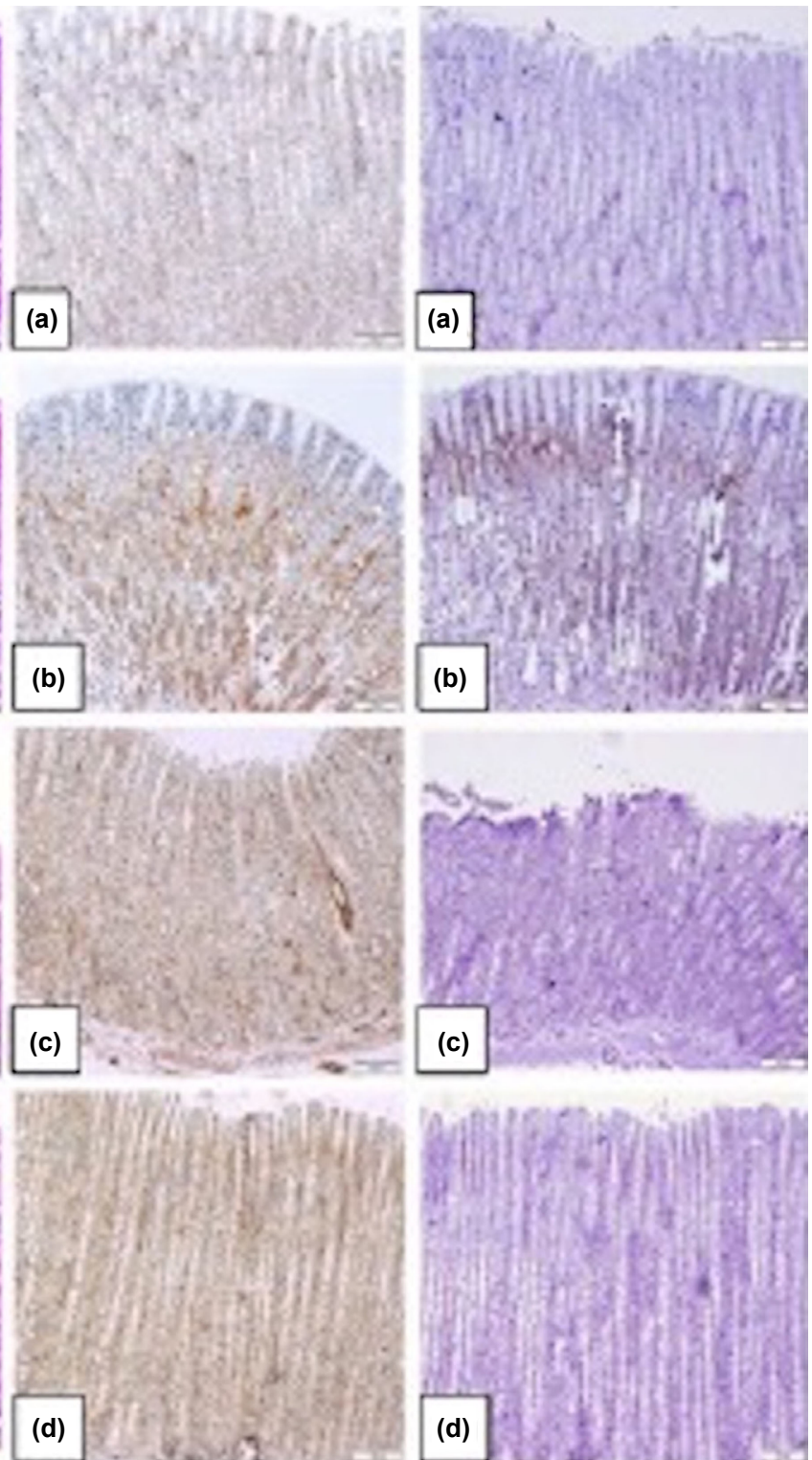

Figure 2. Histopathological studies of the study groups. (a) control group, (b) ulcer group, (c) persimmon $4 \mathrm{~mL} / \mathrm{kg}$ group, (d) persimmon $8 \mathrm{~mL} / \mathrm{kg}$ group. H\&E: Hematoxylin and eosin; NF-kB: Nuclear factor kappa B. 
also enhances NF- $\kappa B$ activation via binding to the TNF- $\alpha$ receptor. ${ }^{[21,22]}$

Excessive proinflammatory gene expression, including ILI $\beta$ and TNF- $\alpha$, have been determined in the gastric tissue following excessive intake of ethanol. ${ }^{[23,24]}$ TNF- $\alpha$ plays a role in the activation of neutrophil infiltration and causes disturbance in gastric microcirculatory. ${ }^{[25]} \mathrm{TNF}-\alpha$ is an important factor gastric ulcer formation as it initiates an acute inflammatory response. ${ }^{[26]}$

NF- $\kappa B$ expression, proinflammatory TNF- $\alpha$, IL-I $\beta$, and anti-inflammatory IL- IO values have previously been shown to increase in a gastric ulcer model study of rats, as seen in our research. ${ }^{[27]}$ In another gastric ulcer model, the TNF- $\alpha$ and caspase- 3 levels were elevated in an ulcer group. ${ }^{[28]}$ Aziz et al. ${ }^{[29]}$ also observed high levels of TNF- $\alpha$, NF- $\kappa B$, and IL- 6 expression in the ulcer group of another ethanol-induced gastric ulcer model.

Persimmon fruit has demonstrated antioxidant activity, and consumption is recommended for several health conditions, including stimulating the immune system, preventing cancer, and reducing inflammation and signs of aging. ${ }^{[30,31]}$

Persimmon has phenolic content, including $\mathrm{p}$-Coumaric acid, gallic acid, syringic acid, vanillic acid, and catechin. [32] Nakano et al. ${ }^{[33]}$ revealed that catechin derivatives downregulated inflammatory cytokine levels, including TNF- $\alpha$ and IL-I $\beta$. Vanillic acid compounds demonstrated anti-inflammatory, antioxidant effects, and inhibition of NF- $\kappa$ B-related proinflammatory cytokine production. ${ }^{[34]}$ It has been reported that the potential antioxidant, antiapoptotic, and anti-inflammatory effects of Gallic acid and P-Coumaric acid may prevent hippocampal neurodegeneration. ${ }^{[35]}$ It has also been demonstrated that gallic acid has a protective effect on cardiotoxicity associated with doxorubicin, and p-Coumaric acid therapy had a beneficial effect on the ototoxicity damage resulting from cisplatin-induced liver and kidney tissue injury. ${ }^{[36]}$ Moreover, it has been reported that chlorogenic acid, $\mathrm{p}$-Coumaric acid, and syringic acid had a positive effect in the treatment of various organ injuries caused by ischemia-reperfusion. ${ }^{[37-39]}$ Another study demonstrated chlorogenic acid and cyanidin 3-glucoside antioxidant activity. ${ }^{[40]}$ Avocado seeds (Persea americana Mill.), which contain epicatechin, have been shown to prevent indomethacin-induced gastric ulcers. ${ }^{[41]}$ Cinnamic acid has been reported to have gastroprotective effects. ${ }^{[42,43]}$ The epicatechin and procyanidin in apple extract have been shown to protect against aspirin-related gastric mucosal injury in rats. ${ }^{[44]}$

In the present study, an ethanol-induced gastric ulcer led to increased IL-10, IL-I $\beta$, IL-6, and TNF- $\alpha$ levels, in addition to increased NF- $\kappa B$ and caspase-3 expression. All of these parameters demonstrate inflammation, but only IL-IO is an anti-inflammatory cytokine, which increases in a suppressive response to elevated proinflammatory cytokines. We found that the administration of persimmon fruit extract had a gastroprotective effect, demonstrating a decrease in all of the study parameters. IL-IO levels and proinflammatory cytokine levels decreased simultaneously. The polyphenolic content of persimmon fruit, which includes catechin, syringic acid, vanillic acid, gallic acid, and p-Coumaric acid, appears to have anti-inflammatory and antioxidant effects.

\section{CONCLUSION}

Persimmon fruit extract demonstrated a gastroprotective effect against an ethanol-induced gastric ulcer model in rats by suppressing proinflammatory parameters and inflammation-apoptosis-related expressions. It is believed that this was likely due to its various polyphenolic ingredients, which have potent anti-inflammatory and antioxidant properties.

A literature review revealed several studies examining the content of persimmon, but no study was found related a potential protective effect in a gastric ulcer model. Our research may provide new insight for gastric ulcer treatment.

Acknowledgements

This study was promoted by our University Department of Scientific Research Projects (Project no: 2016/05I).

This paper was presented in the "I. International Congress on Medicinal and Aromatic Plants: 'Natural and Healthy Life' Book of Abstracts," from the conference held May 10-12, 2017 in Konya, Turkey.

Ethics Committee Approval

Approved by the local ethics committee.

Peer-review

Internally peer-reviewed.

Authorship Contributions

Concept: A.T., E.E., M.C.G., F.N.E.A.; Design: A.T., E.E., M.C.G., F.N.E.A.; Supervision: A.T., E.E., M.C.G., F.N.E.A.; Fundings: M.R.B., A.T., E.E., F.N.E.A.; Materials: M.R.B., E.T., N.K., E.Ç.G., G.Ö.; Data: M.R.B., E.T., N.K., E.Ç.G., G.Ö.; Analysis: A.T., E.E., M.C.G.; Literature search: M.R.B., E.T., N.K., E.Ç.G., G.Ö.; Writing: A.T., E.E., M.C.G.; Critical revision: A.T., E.E., M.C.G.

Conflict of Interest

None declared.

\section{REFERENCES}

1. Hunt RH, Camilleri M, Crowe SE, El-Omar EM, Fox JG, Kuipers EJ, et al. The stomach in health and disease. Gut 2015;64:1650-68.

2. Rodriguez JA, Theoduloz C, Yanez T, Becerra J, SchmedaHirschmann G. Gastroprotective and ulcer healing effect of ferruginol in mice and rats: assessment of its mechanism of action using in vitro models. Life Sci 2006;78:2503-9. [CrossRef]

3. Brown LF, Wilson DE. Gastroduodenal ulcers: causes, diagnosis, prevention and treatment. Compr Ther 1999;25:30-8. [CrossRef]

4. Tanyeli A, Ekinci Akdemir FN, Eraslan E, Güler MC, Nacar T. Anti-oxidant and anti-inflamatuar effectiveness of caftaric acid on gastric ulcer induced by indomethacin in rats. Gen Physiol Biophys 2019;38:175-81. [CrossRef] 
5. Marotta F, Tajiri H, Safran P, Fesce E, Ideo G. Ethanol-related gastric mucosal damage: evidence of a free radical-mediated mechanism and beneficial effect of oral supplementation with bionormalizer, a novel natural antioxidant. Digestion 1999;60:538-43. [CrossRef]

6. Eckhart L, Ballaun C, Uthman A, Kittel C, Stichenwirth M, Buchberger $M$, et al. Identification and characterization of a novel mammalian caspase with proapoptotic activity. J Biol Chem 2005;280:35077-80. [CrossRef]

7. Yagami T, Yamamoto Y, Koma H. Pathophysiological roles of intracellular proteases in neuronal development and neurological diseases. Mol Neurobiol 2019;56:3090-112. [CrossRef]

8. Sun SC. The non-canonical NF-kappaB pathway in immunity and inflammation. Nat Rev Immunol 2017;17:545-58. [CrossRef]

9. Dinarello CA. Overview of the IL-1 family in innate inflammation and acquired immunity. Immunol Rev 2018;281:8-27. [CrossRef]

10. Kishimoto T. IL-6: from its discovery to clinical applications. Int Immunol 2010;22:347-52. [CrossRef]

11. Burada FA, Angelescu C, IOANA M, Mitrut P, Moraru E, Riza A, et al. IL-10 - $1082 \mathrm{~A} / \mathrm{G}$ polymorphism and risk of the gastric cancer. Annals of RSCB 2010;15:93-7.

12. Verma S, Kumar VL. Attenuation of gastric mucosal damage by artesunate in rat: modulation of oxidative stress and NFkappaB mediated signaling. Chem Biol Interact 2016;257:46-53. [CrossRef]

13. Dekanski D, Ristić S, Mitrović DM. Antioxidant effect of dry olive (Olea europaea L.) leaf extract on ethanol-induced gastric lesions in rats. Mediterr J Nutr Metab 2009;2:205-11. [CrossRef]

14. Qi Y, Liu X, Zhang Q, Wu H, Yan D, Liu Y, et al. Carotenoid accumulation and gene expression in fruit skins of three differently colored persimmon cultivars during fruit growth and ripening. SHRTA 2019;248:282-90. [CrossRef]

15. Lee YA, Cho EJ, Tanaka T, Yokozawa T. Inhibitory activities of proanthocyanidins from persimmon against oxidative stress and digestive enzymes related to diabetes. J Nutr Sci Vitaminol (Tokyo) 2007;53:287-92. [CrossRef]

16. Rashed K, Zhang XJ, Luo M, Zheng Y. Anti-HIV-1 activity of phenolic compounds isolated from Diospyros lotus fruits. Phytopharmacol 2012;3:199-207.

17. Biesalski HK. Polyphenols and inflammation: basic interactions. Curr Opin Clin Nutr Metab Care 2007;10:724-8. [CrossRef]

18. Bozhuyuk MR, Pehluvan M, Kaya T, Doğru B. Organic acid composition of selected mulberry genotypes from Aras valley. Atatürk Univ J of the Agricultural Faculty 2016;46:69-74.

19. Capanoglu E, de Vos RC, Hall RD, Boyacioglu D, Beekwilder J. Changes in polyphenol content during production of grape juice concentrate. Food Chem 2013;139:521-6. [CrossRef]

20. Guslandi M. Effects of ethanol on the gastric mucosa. Dig Dis 1987;5:21-32. [CrossRef]

21. Zhou YH, Yu JP, Liu YF, Teng XJ, Ming M, Lv P, et al. Effects of Ginkgo biloba extract on inflammatory mediators (SOD, MDA, TNF-alpha, NF-kappaBp65, IL-6) in TNBS-induced colitis in rats. Mediators Inflamm 2006;2006:92642, [CrossRef]

22. Bradley JR. TNF-mediated inflammatory disease. J Pathol 2008;214:149-60. [CrossRef]

23. Shen Y, Sun J, Niu C, Yu D, Chen Z, Cong W, et al. Mechanistic evaluation of gastroprotective effects of Kangfuxin on ethanol-induced gastric ulcer in mice. Chem Biol Interact 2017;273:115-24. [CrossRef]

24. Chang X, Luo F, Jiang W, Zhu L, Gao J, He H, et al. Protective activity of salidroside against ethanol-induced gastric ulcer via the MAPK/NF-kB pathway in vivo and in vitro. Int Immunopharmacol 2015;28:604-15. [CrossRef]

25. Liu Y, Liang J, Wu J, Chen H, Zhang Z, Yang H, et al. Transformation of patchouli alcohol to beta-patchoulene by gastric juice: beta- patchoulene is more effective in preventing ethanol-induced gastric injury. Sci Rep 2017;7:5591. [CrossRef]

26. Aziza S, Karousa MM, Amin A, Awadalla Ma. Evaluation of gastroprotective effect and anti- inflammatory role of resveratrol against gastric mucosal alterations in experimental model of gastritis in rats. Int J Pharma Sci 2016;6:1559-70.

27. Kolgazi M, Ozdemir-Kumral ZN, Cantali-Ozturk C, Demirci EK, Yuksel M, Sirvanci S, et al. Anti-inflammatory effects of nesfatin-1 on acetic acid-induced gastric ulcer in rats: involvement of cyclo-oxygenase pathway. J Physiol Pharmacol 2017;68:765-77.

28. Tamaddonfard E, Erfanparast A, Farshid AA, Imani M, Mirzakhani $\mathrm{N}$, Salighedar R, et al. Safranal, a constituent of saffron, exerts gastroprotective effects against indomethacin-induced gastric ulcer. Life Sci 2019;224:88-94. [CrossRef]

29. Aziz RS, Siddiqua A, Shahzad M, Shabbir A, Naseem N. Oxyresveratrol ameliorates ethanol-induced gastric ulcer via downregulation of IL-6, TNF-a, NF-kB, and COX-2 levels, and upregulation of TFF-2 levels. Biomed Pharmacother 2019;110:554-60. [CrossRef]

30. Sun L, Zhang J, Lu X, Zhang L, Zhang Y. Evaluation to the antioxidant activity of total flavonoids extract from persimmon (Diospyros kaki L.) leaves. Food Chem Toxicol 2011;49:2689-96. [CrossRef]

31. Sakanaka S, Tachibana Y, Okada Y. Preparation and antioxidant properties of extracts of Japanese persimmon leaf tea (kakinoha-cha). Food Chem 2005;89:569-75. [CrossRef]

32. Gorinstein S, Zachwieja Z, Folta M, Barton H, Piotrowicz J, Zemser M, et al. Comparative contents of dietary fiber, total phenolics, and minerals in persimmons and apples. J Agric Food Chem 2001;49:952-7. [CrossRef]

33. Nakano E, Kamei D, Murase R, Taki I, Karasawa K, Fukuhara $\mathrm{K}$, et al. Anti-inflammatory effects of new catechin derivatives in a hapten-induced mouse contact dermatitis model. Eur J Pharmacol 2019;845:40-7. [CrossRef]

34. Calixto-Campos C, Carvalho TT, Hohmann MS, Pinho-Ribeiro FA, Fattori V, Manchope MF, et al. Vanillic acid inhibits inflammatory pain by inhibiting neutrophil recruitment, oxidative stress, cytokine production, and nfkb activation in mice. J Nat Prod 2015;78:1799808. [CrossRef]

35. Abdel-Moneim A, Yousef AI, Abd El-Twab SM, Abdel Reheim ES, Ashour MB. Gallic acid and p-coumaric acid attenuate type 2 diabetes-induced neurodegeneration in rats. Metab Brain Dis 2017;32:1279-86. [CrossRef]

36. Ekinci Akdemir FN, Albayrak M, Çalik M, Bayir Y, Gülçin İ. The protective effects of $\mathrm{p}$-coumaric acid on acute liver and kidney damages induced by cisplatin. Biomedicines 2017;5:18. [CrossRef]

37. Tanyeli A, Yllmaz Topdağ PE, Ekinci Akdemir FN, Eraslan E, Güler MC. Effectiveness of syringic acid against reproductive organ damage in rats. 45. Ulusal Fizyoloji Kongresi; 2019 Oct 31 - Nov 2; Aydın, Turkey. p. 1.

38. Erdoğan Güzel D, Tanyeli A. Protective effect of p-coumaric acid as free oxygen radical scavenger in experimental renal ischemia-reperfusion model. Sakarya Med 2018;8:625-31.

39. Erdoğan Güzel D, Tanyeli A. P-coumaric acid reduces renal ischemia reperfusion-induced acute lung injury. Sakarya Med 2018;8:644-9.

40. Silva G, Dutra M, Oliveira J, Rybka A, Pereira G, Lima M. Processing methods with heat increases bioactive phenolic compounds and antioxidant activity in grape juices. J Food Biochem 2019;43:e12732. [CrossRef]

41. Athaydes BR, Alves GM, Assis ALEMd, Gomes JVD, Rodrigues RP, Campagnaro BP, et al. Avocado seeds (Persea americana Mill.) prevents indomethacin-induced gastric ulcer in mice. Food Res Int 2019;119:751-60. [CrossRef]

42. Jung J, Lee J-H, Bae KH, Jeong C-S. Anti-gastric actions of eugenol 
and cinnamic acid isolated from Cinnamomi Ramulus. Yakugaku Zasshi 2011;131:1103-10. [CrossRef]

43. Abbas MA, Kandil YI, Disi AM, Jaffal SM. Gastroprotective activity of Loranthus acaciae flower extract in a rodent model of ethanol-in- duced ulcer. Appl Physiol Nutr Metab 2019;44:1283-8. [CrossRef]

44. Paturi G, Butts CA, Bentley-Hewitt KL, McGhie TK, Saleh ZS, McLeod A. Apple polyphenol extracts protect against aspirin-induced gastric mucosal damage in rats. Phytother Res 2014;28:1846-54.

\section{Persimmon (Diospyros Kaki L.) Sıçanlarda Etanol ile İndüklenen Mide Ülserini Hafifletir}

Amaç: Nonsteroid antiinflamatuvar ilaçlar, alkol tüketimi ve Helicobacter pylori, dünya çapında yüksek insidansla mide ülserinin en yaygın nedenleri arasındadır. Aşırı alkol tüketimi sonucu mide mukozasında hasar oluşumu artar. Alkol kaynaklı mide ülseri oluşumunu incelemek ve ülser tedavisi ile ilgili bileşikleri araştırmak için sıçanlarda etanol bazlı mide ülseri modeli kullanılmaktadır.

Gereç ve Yöntem: Persimmon (Diospyros kaki L), Spraque Dawley sıçanlarında $5 \mathrm{ml} / \mathrm{kg}$ etanol ile oluşturulan mide ülseri modelinde uygulandı. Hurmanın mide ülseri üzerindeki olası gastroprotektif etkileri histopatolojik ve biyokimyasal yöntemlerle değerlendirildi.

Bulgular: Persimmon özü, IL-I0, IL-6, TNF- $\alpha$ ve IL-I $\beta$ gibi sitokin düzeylerini önemli ölçüde azalttı. Ayrıca kaspaz-3 ve NF- $\kappa B$ oluşumunu önemli ölçüde düşürdü.

Sonuç: Bu deneysel çalışmanın bir sonucu olarak persimmon, etanol ile oluşturulan mide ülseri modelinde mide koruyucu etki göstermiştir. Anahtar Sözcükler: Etanol; mide ülseri; persimmon meyve ekstresi; sıçan; sitokin. 